\title{
ANTIBACTERIAL EFFECT OF GNETUM GNEMON L. LEAVES EXTRACT ON STAPHYLOCOCCUS AUREUS
}

\author{
Paul J Dayoh ${ }^{1)}$, Endang Isbandiati' ${ }^{2)}$, Titien Rahayu ${ }^{3)}$
}

\begin{abstract}
Introduction: Bacterial infections are common among doctors in Indonesia, leading to increased use of antibiotics. Increased use of antibiotics, if not accompanied by rational indication, can increase bacterial resistance. At present, alternative medicine from natural ingredients is widely studied, one of which is the leaves of melinjo (Gnetum gnemon L.). Melinjo leaves are thought to contain antibacterial compounds such as flavonoids, tannins, saponins, and alkaloids. Staphylococcus aureus is a round Gram-positive bacteria, that forms grape-like clusters. Staphylococcus aureus is a normal flora on the skin and human mucosa but can be opportunistic pathogens that cause mild to severe infections such as sepsis. Pathogenic Staphylococcus aureus can produce hemolysis blood, frozen plasma, and produce various extracellular enzymes and toxins.

Purpose: This research aims to study the MIC and MBC of melinjo leaves extract on the growth of Staphylococcus aureus bacteria. This research is an experimental study with a posttest control group design.

Method: Testing conducted using the microdilution method. Melinjo leaves used were extracted by maceration method using $96 \%$ ethanol. Samples were Staphylococcus aureus ATCC 25923 from BBLK Surabaya.

Results: extract of melinjo leaves (Gnetum gnemon L.) had MIC on Staphylococcus aureus bacteria at a concentration of $640 \mathrm{mg} / \mathrm{ml}$. MBC was not obtained because the extract of melinjo leaves clotted above $1280 \mathrm{mg} / \mathrm{ml}$ concentration.
\end{abstract}

Conclusion: Melinjo leaves extract has an antibacterial effect against Staphylococcus aureus, the MIC is obtained at a concentration of $640 \mathrm{mg} / \mathrm{ml}$, and the MBC cannot be determined.

Keywords: Antibacterial, Gnetum gnemon L., Staphylococcus aureus, Microdilution Minimum Inhibitory Concentration, Minimum Bactericidal Concentration

\footnotetext{
${ }^{1)}$ Student of Faculty of Medicine, Widya Mandala Surabaya Catholic University Indonesia, Jl. Kalisari Selatan No.1 Surabaya Email: jhosua_paul@gmail.com

${ }^{2)}$ Clinical Pharmacology Department, Faculty of Medicine, Widya Mandala Surabaya Catholic University Indonesia, J1. Kalisari Selatan No.1 Surabaya

${ }^{3)}$ Clinical Pathology Department, Faculty of Medicine, Widya Mandala Surabaya Catholic University Indonesia, Jl. Kalisari Selatan No.1 Surabaya
} 


\section{INTRODUCTION}

In Indonesia, bacterial infections are common among clinicians, both in hospitals and private practice, which also causes an increase in the use of antibiotics. Data from the Proceedings of the National Academy of Sciences of the United States of America (PNAS 2018) states that in 2000-2015 there was an increase in the use of antibiotics in the world by $65 \%$, especially in the United States, France, and Italy in the broad-spectrum penicillins, cephalosporins, quinolones, and macrolides class ${ }^{1}$. World Health Organization (WHO 2015) states that about $64 \%$ of antibiotics are purchased without using a prescription in Southeast Asia. High rates on the use of antibiotics without a prescription in Southeast Asia are caused by low public awareness regarding appropriate use of antibiotics ${ }^{2}$.

Irrational use of antibiotics can increase bacterial resistance rates. According to the Centers for Disease Control (CDC 2013), there are around $2,049,442$ cases of illness due to antibiotic resistance and about 23,488 cases of death $^{3}$. Some theories of resistance include the production of enzymes that can deactivate antibiotics, changes in the structure of target receptors, and decreased bacterial cell membrane permeability for antibiotics ${ }^{4}$. The CDC has made several recommendations for reducing antibiotic resistance, including the selection of antibiotics based on local sensitivity patterns, the use of appropriate and careful catheters, proper antiseptic techniques, infection control procedures to isolate pathogens, patient compliance with antibiotic use, and hand sanitation, and always pay attention to the cleanliness of the environment around the patient ${ }^{5}$.

Infection is the process of microorganisms entering the body, multiplying and causing severe health problems. Bacteria can enter the body through wounds on the mucous membranes, respiratory tract, digestive tract, or genital and urinary tracts ${ }^{6}$. One of the bacteria that can infect humans is Staphylococcus aureus. Staphylococcus is round-shaped Gram-positive bacteria with a diameter of 0.7 to $1.2 \mu \mathrm{m}$, that do not move, do not produce spores, and are arranged in grape-like clusters ${ }^{7}$. Some Staphylococcus species are normal flora on the skin and human mucosa, while other species can cause pus, abscess formation, various pyogenic infections, and even fatal septicemia. Pathogenic Staphylococcus can produce hemolysis blood, freeze plasma, and produce multiple extracellular enzymes and toxins. The toxin produced by Staphylococcus is an enterotoxin that is stable to heat and can cause food poisoning ${ }^{6}$. 
Indonesia is a country with a lot variety of natural resources ${ }^{8}$. According to the Republic of Indonesia Health Office (2007), an estimated 9,600 species grow in Indonesia and have medicinal properties. Still, only around 300 species have been used as traditional medicine. One of them is melinjo plant. Melinjo leaves and fruit are often processed into vegetables, and melinjo fruit seeds are processed into chips. parts of melinjo seeds are often used in herbal medicine research as natural antibacterial. According to Siswoyo (2007), anti-bacterial from melinjo plants can be found in the seeds, skins, and leaves of melinjo plants ${ }^{9}$.

phytochemical examination of melinjo leaves found that melinjo leaves contain several anti-bacterial compounds including flavonoids, tannins, saponins, and alkaloids $^{10,11}$.

Flavonoids are very lipophilic compounds that make it possible to damage bacterial membranes. The antibacterial effect of flavonoids is suspected to involve three mechanisms: First, by inhibiting nucleic acid synthesis. Second, by damaging the cytoplasmic membrane, For example, the addition of galangin to Staphylococcus aureus bacteria cause potassium leakage. Finally, by inhibiting the metabolism of energy in bacteria. Examples of administration of apigenin and naringenin alter the outer membrane and cytoplasm of Enterobacter cloacae cells, thus interfering with the exchange of nutrients and metabolites and ultimately inhibiting the supply of energy for bacteria $^{12,13,14,15,16}$. Anti-bacterial activity against Staphylococcus aureus shows that flavone, a flavonoid compound, significantly suppresses the production of staphyloxanthin and $\alpha$-hemolysin ${ }^{17}$. Tannins are phenolic compounds that can interfere with iron absorption by forming complex bonds with iron, thereby reducing the bioavailability of iron in bacteria ${ }^{18}$. Saponin has an anti-bacterial mechanism by disrupting the balance of surface permeability of bacterial cell membranes. Cell membrane damage can occur and causes various important components to come out of the bacterial cell, such as proteins, nucleic acids, and nucleotides ${ }^{19}$. The alkaloid anti-bacterial effect has several mechanisms, first by inhibiting the synthesis of nucleic acids because they inhibit the enzyme dihydrofolate reductase, secondly by interrupting the Z-ring, thereby inhibiting cell division and inhibiting the synthesis of nucleic acids. Finally, penetration of the outer membrane and distruption of the integrity of the bacterial cytoplasmic membrane, which causes intracytoplasmic leakage ${ }^{20}$.

Research on the use of melinjo leaves as an anti-bacterial is still minimal in data and scientific sources. Therefore we are 
interested in examining the anti-bacterial effect of extracts of melinjo leaf (Gnetum gnemon L.) on Staphylococcus aureus.

\section{METHOD}

This research is an experimental study with a post-test control group design. This research was conducted at the Phytochemical-Pharmacogenomic Laboratory of the Faculty of Pharmacy Widya Mandala Catholic University Surabaya, the Surabaya Health Laboratory Center (BBLK) in Faculty of Pharmacy Research Laboratory in Widya Mandala Catholic University Surabaya. The population of this research is Staphylococcus aureus. The sample used was the bacterium Staphylococcus aureus ATCC 25923. The concentration of melinjo leaf extract used was 40-640 $\mathrm{mg} / \mathrm{ml}$.

\section{The Making of Extracts}

Melinjo leaf powder that has been obtained from UPT Batu City Medical Material was taken to the PhytochemicalPharmacogenomic Laboratory of the Faculty of Pharmacy Widya Mandala Catholic University Surabaya to be extracted. The extraction process was carried out by maceration method using $96 \%$ ethanol solvent for 24 hours, then remaseration was carried out. The ethanol liquid extract obtained was then concentrated using Waterbath to get a thick extract. The thick extract was obtained then the yield was calculated.

\section{The Making of Extract concentrations}

The results of ethanol extract of melinjo leaves obtained after maceration, then diluted with Dimethyl sulfoxide 2\% (DMSO) to form concentrations of 40 $\mathrm{mg} / \mathrm{ml}, 80 \mathrm{mg} / \mathrm{ml}, 160 \mathrm{mg} / \mathrm{ml}, 320 \mathrm{mg} / \mathrm{ml}$, and $640 \mathrm{mg} / \mathrm{ml}$.

\section{Bacteria Preparation}

Staphylococcus aureus ATCC 25923 bacterial culture was regenerated to obtain bacterial culture in the growth phase. Regeneration was carried out on MuellerHinton broth media and then incubated for 24 hours at $37^{\circ} \mathrm{C}$ in an incubator. Microscopic and biochemical tests (catalase tests, coagulase tests, and mannitol tests) were carried out to ensure that the bacteria used are not contaminated.

\section{Antibacterial Test}

Antibacterial activity testing was carried out by the microdilution method. This study was divided into two groups, namely the control group and the treatment group. 
$\mathrm{K} 1-5=$ The control group consisted of

K1 = Mueller-Hinton Broth

K21-5 $=$ Mueller Hinton Broth + melinjo leaves extract (Gnetum gnemon L.) at concentration $40-640 \mathrm{mg} / \mathrm{ml}$

$\mathrm{K} 3=$ Mueller Hinton Broth + Staphylococcus aureus

$\mathrm{K} 4=$ Mueller Hinton Broth + DMSO 2\% + Staphylococcus aureus

$\mathrm{K} 5=$ Mueller Hinton Broth + Penicillin $0,12 \mu \mathrm{g} / \mathrm{ml}+$ Staphylococcus aureus

P1-5 = Mueller Hinton Broth + Staphylococcus aureus + melinjo leaves extract (Gnetum gnemon L.) at concentration $40-640 \mathrm{mg} / \mathrm{ml}$.

Then the microplate was incubated for 24 hours at $37^{\circ} \mathrm{C}$. After waiting 24 hours, the microplate was observed with turbidity using a microplate reader. The MIC was determined based on the percentage inhibition of $\geq 90 \%$. The MIC is measured by calculating the percentage of resistance from the absorbance value or optical density (OD) obtained from the microplate reader/microplate spectrophotometer.

MBC was observed by subculture by streaking or streaking a small portion of the results of microplate incubation tubes into gelatine. The results of streaking were not found in the growth of bacteria to be determined as MBC.

\section{RESULTS}

Optical density (OD) values on spectrophotometer readings (Table 1) indicate that optical density values do not show linear results.

Tabel 1. Optical density result

\begin{tabular}{|c|c|c|}
\hline Concentration & $\begin{array}{l}\text { Optical density } \\
\text { value }\end{array}$ & Mean \\
\hline $\mathrm{P} 1$ & $\begin{array}{l}0,3885 \\
0,3947 \\
0,4012 \\
0,3716 \\
0,3861 \\
\end{array}$ & 0,3884 \\
\hline $\mathrm{P} 2$ & $\begin{array}{l}0,3018 \\
0,2897 \\
0,3101 \\
0,3197 \\
0,3080 \\
\end{array}$ & 0,3058 \\
\hline P3 & $\begin{array}{l}0,6208 \\
0,5963 \\
0,6007 \\
0,6021 \\
0,6063 \\
\end{array}$ & 0,60524 \\
\hline P4 & $\begin{array}{l}0,4011 \\
0,3993 \\
0,3964 \\
0,4013 \\
0,3989 \\
\end{array}$ & 0,3994 \\
\hline P5 & $\begin{array}{l}0,1712 \\
0,2005 \\
0,1673 \\
0,1719 \\
0,1986 \\
\end{array}$ & 0,1819 \\
\hline
\end{tabular}

Because the optical density value obtained was not linear, it was entered into the formula to get the MIC (Minimal Inhibitory Concentration). 
Tabel 2. Percentage of bacterial inhibition per concentration

\begin{tabular}{|c|c|c|}
\hline Concentration & $\begin{array}{l}\text { Optical density } \\
\text { value }\end{array}$ & Mean \\
\hline $\mathrm{P} 1$ & $\begin{array}{l}64,19 \% \\
63,36 \% \\
62,46 \% \\
66,52 \% \\
64,54 \% \\
\end{array}$ & $64,21 \%$ \\
\hline $\mathrm{P} 2$ & $\begin{array}{l}71,42 \% \\
73,08 \% \\
70,28 \% \\
68,95 \% \\
70,57 \% \\
\end{array}$ & $70,86 \%$ \\
\hline P3 & $\begin{array}{l}72,24 \% \\
75,61 \% \\
75,01 \% \\
74,81 \% \\
74,23 \%\end{array}$ & $74,38 \%$ \\
\hline P4 & $\begin{array}{l}78,08 \% \\
78,34 \% \\
78,73 \% \\
78,06 \% \\
78,39 \%\end{array}$ & $78,32 \%$ \\
\hline P5 & $\begin{array}{l}95,97 \% \\
91,96 \% \\
96,51 \% \\
95,87 \% \\
92,22 \%\end{array}$ & $96,16 \%$ \\
\hline
\end{tabular}

Table 2 shows that the higher the concentration of melinjo leaf extract, the higher the percentage of inhibition to Staphylococcus aureus bacteria. The highest percentage of inhibition was at a concentration of $640 \mathrm{mg} / \mathrm{ml}$, which is above $90 \%$.

\section{DISCUSSION}

\section{MIC Test (minimum inhibitory concentration)}

The MIC test in this study was carried out by reading the spectrophotometry from the results of microdilution incubation. In Table 1, the results of spectrophotometric readings are found to be non-linear. This is due to the bias of the turbidity of the extract used, so the optical density values obtained cannot be used as data in analysis. These values must be converted into a percentage. After receiving the percentage, the data was then processed in SPSS.

The percentage of inhibition in the microdilution test showed MIC at a concentration of $640 \mathrm{mg} / \mathrm{ml}$. This concentration was obtained after the first microdilution trials with sequential concentrations of $5,10,20,40,80 \mathrm{mg} / \mathrm{ml}$ not achieving MIC and MBC. Hence, we increased the concentration to $640 \mathrm{mg} / \mathrm{ml}$ in the second trial.

There are no studies with microdilution methods similar to this study. Previous research was conducted by Fitri (2017) with a diffusion test to determine the diameter of the resistance zone. The results of Fitri's research (2017) showed inhibition zone diameter in ethanol extract of melinjo leaves (Gnetum gnemon L.) against Staphylococcus epidermidis at concentrations of $10 \%, 20 \%, 30 \%, 40 \%$, $50 \%$, and $100 \% \mathrm{w} / \mathrm{v}$, respectively. 
Obtained diameter inhibitory zones respectively of $2.65,22.02,22.33,25.09$, 26.15 , and $26.79 \mathrm{~mm}^{21}$. In that study, clindamycin antibiotic was used as a positive control with a zone of inhibition of $42.85 \mathrm{~mm}$. The largest inhibitory zone diameter in Fitri's study (2017) was 26.79 $\mathrm{mm}$ at a concentration of $100 \% \mathrm{w} / \mathrm{v}$ (equivalent to $100 \mathrm{~g} / 100 \mathrm{ml}$ or 1000 $\mathrm{mg} / \mathrm{ml}$ ). The results of her study indicate that the ethanol extract of melinjo leaves has an inhibitory effect on the growth of Staphylococcus epidermidis bacteria ${ }^{21}$. If compared with results of this study, inhibition was also found in ethanol extract of melinjo leaves against Staphylococcus aureus bacteria. At concentrations of 640 $\mathrm{mg} / \mathrm{ml}$ and $1280 \mathrm{mg} / \mathrm{ml}$ extract of melinjo using the microdilution method, Staphylococcus aureus bacterial growth inhibition was greater than $90 \%$, but because it did not kill $99.9 \%$ of bacteria, only MIC was obtained. This reinforces previous research on the antibacterial effect of melinjo leaf extract.

\section{MBC Test (minimum bactericidal concentration)}

The MBC test in this study was carried out by streaking from the microplate incubation results of the treatment group into blood agar media. Visual observations showed that all plates still contained bacterial growth, which indicated that no concentration could inhibit bacterial growth by $99.9 \%$.

The MBC value in this study cannot be determined because, at a concentration of $1280 \mathrm{mg} / \mathrm{ml}$, the percentage of growth inhibition of the Staphylococcus aureus bacteria was found to be above $90 \%$ but does not inhibit bacterial growth to $99.9 \%$. at concentrations above $1280 \mathrm{mg} / \mathrm{ml}$, the melinjo leaf extract does not become a liquid form as in concentrations below $1280 \mathrm{mg} / \mathrm{ml}$. Instead, it remains in semisolid form, so that concentration cannot be made. Microdilution tests cannot be carried out. Semisolid form occurs because of the hygroscopic nature of melinjo leaves. At high concentrations (in this study above $1280 \mathrm{mg} / \mathrm{ml}$ ), it is suspected that the volume of the solvent used cannot compensate for the hygroscopic nature of melinjo leaves, so the extract remains in semisolid form.

In previous studies, no studies have used microdilution or macro dilution methods to determine the $\mathrm{MBC}$ of melinjo leaf extract, so researchers cannot compare current research results with previous studies.

\section{CONCLUSION}

Based on the study results, it can be concluded that melinjo leaf extract has an antibacterial effect against Staphylococcus aureus bacteria with a minimum inhibitory 
concentration at a concentration of 640 $\mathrm{mg} / \mathrm{ml}$, while a minimum bactericidal concentration cannot yet be determined.

\section{REFERENCES}

1. Laxminarayan R, Goossens H, Klein EY, Gandra S, Pant S, Levin SA, et al. Global increase and geographic convergence in antibiotic consumption between 2000 and 2015. Proc Natl Acad Sci. 2018;115(15):1-8 p.

2. WHO. Worldwide country situation analysis: Response to Antimicrobial Resistance. WHO Libr Publ data [Internet]. 2015; Available from: http://www.who.int/drugresistance/doc uments/situationanalysis/en/

3. U.S. Department of Health and Human Services. Antibiotic resistance threats in the United States. [Internet]. 2013;114. Available from: http://www.cdc.gov/drugresistance/thr eat-report-2013/index.html

4. Trevor AJ, Katzung BG, KruideringHall M, Masters SB. Pharmacology Examination \& Board Review Tenth Edition. 10th ed. New York: McGraw Hill Medical; 2013: 381 p.

5. Goodman LS, Gilman A, Brunton LL, Parker KL, Blumenthal DK, Buxton LO. Goodman and Gilman's Manual of Pharmacology and Therapeutics.
New York : McGraw-Hill; 2008: 671$72 \mathrm{p}$.

6. Brooks GF, Jawetz E, Aldeberg EA. Jawetz, Melnick \& Adelberg's medical microbiology. 26th edition. New York: Mcgraw-Hill Medical; 2013. 1-817 p.

7. Bhatia R, Ichhpujani RL. Essentials of Medical Microbiology. 4th edition. New Delhi: Jaypee Brothers Medical Publishers; 2008. 1-489 p.

8. Departemen Kesehatan Republik Indonesia. Kebijakan Obat Tradisional Nasional. Departemen Kesehatan Republik Indonesia. 2007: 1-42 p.

9. Siswoyo TA. Free Radical Scavenging Activity and Phenolic Content of Melinjo Tree (Gnetum gnemon L.). 2007: $221 \mathrm{p}$

10. ITIS. Gnetum gnemon L. [Internet]. 2010 [cited 2019 Apr 9].

11. Alvita LR. Aktivitas Antibiofilm Dari Bakteri Escherichia coli Oleh Ekstrak Air Daun Singkong, Pepaya Dan Melinjo Secara In Vitro. 2015;9-10 p.

12. Panche AN, Diwan AD, Chandra SR. Flavonoids: an overview. J Nutr Sci. 2016;5:1-15 p.

13. Nagula RL, Wairkar S. Recent advances in topical delivery of flavonoids: A review [Internet]. Vol. 296, Journal of Controlled Release. Elsevier B.V; 2019. 190-201 p. Available from: 
https://doi.org/10.1016/j.jconrel.2019. $\underline{01.029}$

14. Ulanowska K, Tkaczyk A, Konopa G, Wȩgrzyn G. Differential antibacterial activity of genistein arising from global inhibition of DNA, RNA and protein synthesis in some bacterial strains. Arch Microbiol. 2006;184(5):271-8 p.

15. Cushnie TPT, Lamb AJ. Detection of galangin-induced cytoplasmic membrane damage in Staphylococcus aureus by measuring potassium loss. $\mathrm{J}$ Ethnopharmacol. 2005;101(1-3):243$8 \mathrm{p}$.

16. Eumkeb G, Chukrathok S. Synergistic activity and mechanism of action of ceftazidime and apigenin combination against ceftazidime-resistant Enterobacter cloacae. Phytomedicine [Internet]. Elsevier GmbH.; 2013;20(3-4):262-9 p. Available from:

http://dx.doi.org/10.1016/j.phymed.20 $\underline{12.10 .008}$

17. Kong C, Neoh HM, Nathan S. Targeting Staphylococcus aureus toxins: A potential form of antivirulence therapy. Toxins (Basel). 2016;8(3):1-21 p.

18. Widsten P, Heathcote C, Kandelbauer A, Guebitz G, Nyanhongo GS, Prasetyo EN, et al. Enzymatic surface functionalisation of lignocellulosic materials with tannins for enhancing antibacterial properties. Process Biochem [Internet]. Elsevier Ltd; 2010;45(7):1072-81 p. Available from:

http://dx.doi.org/10.1016/j.procbio.201 $\underline{0.03 .022}$

19. Purbowati O. Pengaruh Campuran Ekstrak Tanaman Binahong (Anredera cordifolia (Ten.) Steenis) dan Sambiloto (Andrographins paniculata Nees) terhadap Kadar Glukosa Darah Tikus Putih (Rattus norvegicus L.) Jantan. Departemen Biologi Fakultas Matematika dan Ilmu Pengetahuan Alam Universitas Indonesia. 2011

20. Cushnie TPT, Cushnie B, Lamb AJ. Alkaloids: An overview of their antibacterial, antibiotic-enhancing and antivirulence activities. Int $\mathrm{J}$ Antimicrob Agents [Internet]. Elsevier B.V.; 2014;44(5):377-86. Available from:

http://dx.doi.org/10.1016/j.ijantimicag. 2014.06.001

21. Hidayah FA, Setiawan NCE. EFEKTIVITAS EKSTRAK ETANOL DAUN MELINJO ( Gnetum gnemon L .) TERHADAP BAKTERI Staphylococcus epidermidis. 2017;4-7 